\title{
Contemporary Udmurt Culture. I, II
}

Современная удмуртская культура, Том 1, Том 2, редсост. Ева Тулуз, Елена Попова, Николай Анисимов, Таллинн 2020-2021, Изд. Таллиннского Университета. [Contemporary Udmurt Culture.] I, II. Edited by Eva Toulouze, Nikoli Anisimov, Elena Popova. Tallinn: Tallinn University Press.

Many interesting books are born out of international cooperation. Often cooperation agreements between academic institutions are purely formal, their function primarily declarative: we have many good partners abroad, we are connected with so many international institutions. But sometimes this cooperation indeed exists and gives good results. This is the case with the two-volume work being reviewed here: Contemporary Udmurt Culture, published by the University of Tallinn, but relying on work conducted by both the Udmurt Research Institute and the Estonian Literary Museum. Behind the institutional reality, however, there is human agency: the initiators of this book, the editors, are a group of scholars who have long been acquainted through different international events and have had the opportunity to discuss several issues which led to the desire to achieve this work.

They explain all this in the prefaces to the two volumes that compose this work. The research area into which this
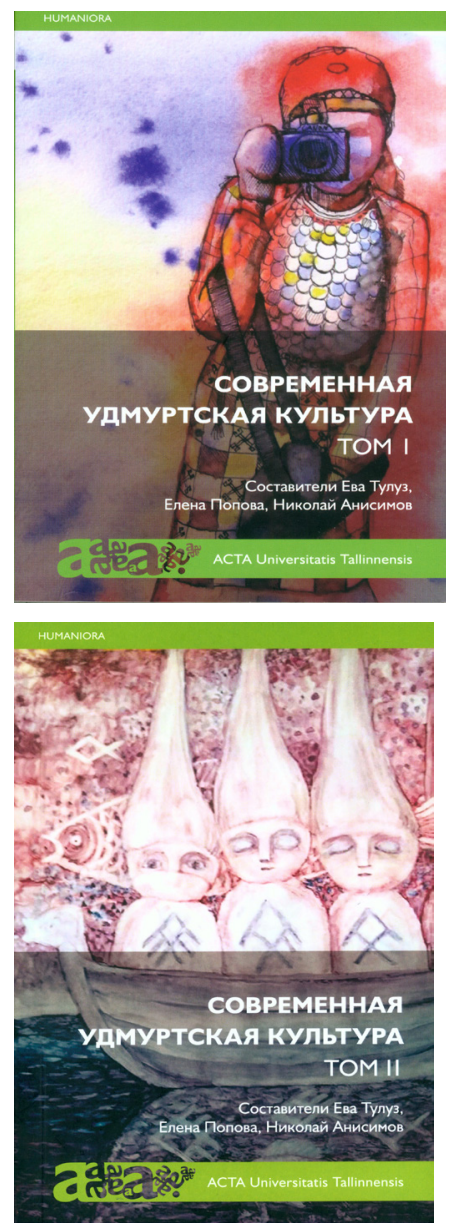
book is integrated may be called Udmurt Studies. Of course, most readers of this review will never have heard of Udmurt Studies: the Udmurt are just one of the many peoples that make up the Russian Federation, and, as is the case with most minorities in the world, they remain in the shadow of the dominant ethnic group, the Russians. What is true for most of the world, however, is not the case in Estonia, due to a curious identity phenomenon that deserves to be explained in detail. While language plays different possible roles, depending on the community, for Finno-Ugric communities it plays a most central role. Well aware that their languages differ very greatly from those surrounding them, the peoples who speak these languages - especially the three living in Europe and involved in the European national awakening inspired by Herder's ideas, namely Hungarians, Finns and Estonians, and more particularly these peoples' elites - have long been looking for their roots. Closely connecting identity and language, they have looked for the ancestor common to their languages, namely Proto-Finno-Ugric, and have attempted to reconstruct it through linguistic comparison by collecting materials in the field, accumulating data and elaborating on them. Thus, there is a tradition with respect to Finnish and Hungarian, and followed marginally by Estonians, of feeling a particular connection with communities speaking a language of the same origin. Therefore, Finno-Ugric studies are particularly developed in these scholarly communities, and it is not surprising to find this kind of cooperation project being born within this framework. It is always hard to feel alone in the world, and when small minorities have the luck to be able to rely on benevolent 'elder brothers', they take fully advantage of the fact.

This explains why the Estonian Literary Museum, like other research institutions in Estonia, has acquired pretty extensive expertise on Finno-Ugric matters and publishes abundant new research literature on these subjects. Nevertheless, as the two volumes of Contemporary Udmurt Culture reveal, Udmurt culture is still mostly investigated by Udmurt scholars. In these volumes only four scholars are not Udmurt: one Estonian, one Russian, one Austrian and one Franco-Estonian. This is actually one of the weaknesses of Udmurt research nowadays: these is too little of the external point of view, too little dialogue between insiders and outsiders.

Anyhow, the initiators of this huge achievement started from a simple observation: they regretted that Udmurt research is focused too exclusively on the past. This is, of course, understandable for those who know that the Russian 
tradition includes ethnology in historical research: its goal is to reconstruct a lost past for which the only resources are the memories of the elderly. However, the three editors are all devoted fieldworkers, well aware of both the richness of current Udmurt materials and the depth of ongoing transformations. If nobody investigates now, how will Udmurt research fare in the future?

This extremely rich collection of articles, enlivened by numerous photos, is indeed the result of the cooperation of many fieldworkers. All the authors rely on their own fieldwork and experiences, which produces vivid articles in which their respective personalities appear very clearly. They have attempted to cover many fields while leaving others unexplored. They have attempted to cover ritual life today: how commemorations of the dead are performed (Anisimov), the regional ritual Aykay (Nurieva), the regular religious practice of both traditional animist 'religion' (Toulouze, Vallikivi, Chernykh) and Orthodox worship (Shushakova, Bulycheva), and current reflections on the influence of the present COVID-19 pandemic on Udmurt rituals (Anisimov, Glukhova). The authors also cover festive life and entertainment: the renovated form of a relaxing house, pukon korka (Vladykina, Boldyreva); the modern Udmurt Gerber feast (Shutova), and the equivalent in Eastern Udmurt regions, sabantuy (Sadikov); ethnic and identity mobilization, with an analysis of different ethnic projects in a touristic framework (Vlasova, Obukhov); social activism (Perevozchikov, Stepanov); and identity markers (Russkikh). One may also include in this category Popova's article about food as an ethnic marker. Other topics are more or less systematically treated: there is a category covering literature today (Fedorova, Panteleyeva, Arekeyeva, Dmitriyeva, Vekshina), and another on music both in a rural environment (Pchelovodova) and on stage (Anfinogenov). The language issue, a huge one, is brushed up on with Pischlöger's article, which awakens our appetite, although we would definitely wish for more nourishment. Other interesting chapters deal with classic ethnographic subjects, such as rural architecture (Perevozchikov) and costume (Popova), while others widen the scope with less classical issues: the ethnic aspect in art (Kovycheva), modern aesthetics (Kasimova), communication patterns (Russkikh), and ethnobotanics and food (Suntsova). Finally, one article follows one family's life through photos across one century, emphasizing its different migrations and changes in life and world-view.

In spite of the abundance of issues and the length of the two books (399 and $488 \mathrm{pp}$.), there are many fields that remained untouched, or pretty much 
untouched. Certainly, there is much to say about language and many interesting sub-topics: literary language use, dialects, influences and the use of translation in everyday life. In Udmurt society, ritual life is also much richer than it appears here. Many different events are ritualized without us always using the word 'ritual' for them, such as student holidays, military service, graduations, funerals, relations between kin, weddings, communication between the sexes and generations, social stratification, drinking, driving cars and structures of power. The aim of these volumes was certainly not, as the preface admits, to cover the whole field. But they awaken curiosity, prompting the wish to know more.

What is the interest in these volumes for different audiences? First of all, there has been an attempt to make it accessible to the Udmurt. It is written in Russian, so it may be read by the people the authors talk about. This is clearly very important, in order to tighten the links and trust between the fieldworkers and their informants, who may appreciate their own contribution to scientific research and at the same time check on the output of the ethnographer's or folklorist's work. This volume may also open up more widely the huge field of comparative research in Russia: in other regions, colleagues may be inspired to follow analogous themes and to pinpoint differences and similarities.

The most important aspect, which is also the most innovative one, it how this work opens up contemporary research on the Udmurt. On the one hand, there is now a precedent, a basis allowing further work to be pursued in this direction. But also, and more importantly, many scholars have been compelled to make a fundamental effort to get off the beaten track. They have discovered new possible approaches, and some of them have continued in this spirit since writing the chapters in this work.

Pavel Kutergin

University of Tartu.

kuterezhik@mail.ru

Pavel Kutergin is a Doctoral student in ethnology at the University of Tartu. He investigates the Udmurt folklore ensembles' activities as means to promote Udmurt folk culture. 